深海化学合成生物群集から出現するベントスのエネルギー獲得戦略： 軟体部の炭素, 窒素および硫黄の安定同位体組成による解析

\title{
Strategic Adaptation of a Deep-sea, Chemosynthesis-based Animal Community: An Evaluation Based on Soft Body Part Carbon, Nitrogen, and Sulfur Isotopic Signatures
}

\author{
溝田智俊 ${ }^{1) * *}$ ・ 山中寿朗 ${ }^{21}$ \\ 1) 岩手大学農学部。广 020-8550 盛岡市上田 3-18-8 \\ 2) 九州大学大学院・比較社会文化研究院：干 810-8560 福岡市中央区六本松 4-2-1
}

Chitoshi MIZOTA $^{1) *}$ and Toshiro YAMANAKA ${ }^{2)}$

1) Faculty of Agriculture, Iwate University, Ueda 3-18-8, Morioka 020-8550, Japan

${ }^{2)}$ Department of Evolution of Earth Environments, Graduate School of Social and Cultural Studies, Kyushu University, Ropponmatsu, Fukuoka 810-8560, Japan

\begin{abstract}
Benthic animals that rely on endosymbiotic bacteria for their nutrition are ubiquitous around deep-sea hydrothermal vents and cold seeps where hydrogen sulfide together with methane is issuing. To elucidate the strategic adaptation of these animals to these environments, relevant analytical data on the carbon, nitrogen, and sulfur isotopic signatures of the soft body were compiled and evaluated in relation to those of hydrogen sulfide, methane, and ammonia in the habitat. The soft body part carbon isotopic compositions $\left(\delta^{13} \mathrm{C}\right)$ of pogonophorans, vesicomyid and solemyid clams, gastropods, and Bathymodiolus spp. in which sulfur-oxidizing bacteria are the sole endosymbiont, varied within a relatively narrow range of $-35 \pm 5 \%$, which indicates catalytic fixation of dissolved bicarbonate by ribulose-1,5biphosphate carboxylase/oxygenase. In contrast, benthic animals habouring methanotrophic endosymbionts showed a wider variation in ranges of carbon isotopic composition, from extremely light $\left(\delta^{13} \mathrm{C}=-70 \% 0\right)$ to heavy $\left(\delta^{13} \mathrm{C}=\right.$ $-19 \% 0$ ). The variation results from the diverse sources of the substrate methane and associated specific metabolic pathways. Soft body part sulfur isotopic composition $\left(\delta^{34} \mathrm{~S}\right)$ of benthic animals harbouring methanotrophic bacteria showed a narrow range of +13 to $+16 \%$, indicating incorporation and assimilation of seawater sulfate $\left(\delta^{34} \mathrm{~S}=+21 \%\right.$ ) under a limited kinetic, sulfur isotopic fractionation (up to $6 \%$ ). The benthic animals harbouring sulfur-oxidizing bacteria showed ${ }^{34} \mathrm{~S}$ values from light (down to $-20 \%$ ) to near 0 , in accordance with the biogenic and magmatic origins of the sulfur, respectively. Two samples of Bathymodiolus spp. with dual symbiosis from the South Chamorro Seamount and Gulf of Mexico showed intermediate $\delta^{34} \mathrm{~S}$ values, which indicate use of both heavy seawater sulfate-sulfur and light sulfide-sulfur in their nutrition. Animals that rely on chemosynthesis for nutrition are characterized by their unique soft body part nitrogen isotopic signatures with fairly light values down to $-10 \%$, values that are seldom observed in terrestrial and ordinary marine ecosystems. Such light values may be inherited from the source inorganic nitrogen or they may arise from large-scale nitrogen isotopic fractionation in the course of metabolic pathways. Data concerning the nitrogen isotopic composition of the dissolved ammonia associated with chemosynthesis-based animal community is needed.
\end{abstract}

Key Words: Bathymodiolus spp., carbon, chemosynthesis-based community, endosymbiosis, nitrogen, stable isotope, sulfur, vesicomyid clam.

\section{はじめに}

太陽の光エネルギーは, 葉緑体を持つ珪藻などの植物プ ランクトン類および高等植物に生体高分子という形態の化

Received 31 Jan. 2003 Accepted 28 Apr. 2003

*: Corresponding author
学エネルギーとして眝蔵され, 生命活動に伴って随時開放 される.このエネルギー固定過程は, 出発材料がすべて無 機物であることから, 光合成独立栄養系と呼ばれ, 地球上 での生物圈のエネルギー基盤をなしている.これに対し て, 一般の微生物や高等動物は, 光合成過程を通して固定 された有機物を燃焼して生命活動を行うため, 従属栄養生 物といわれる.

海の生物圈に目を向けてみると, 太陽光の到達する海水 
の深度はせいせい $200 \mathrm{~m}$ 程度であるから, それより深い海 では, 生物の密度は通常は著しく低い, ところが, 1970 年 代の終わり頃から, 海底の熱水噴出孔の周辺に, 特異な生 態系が展開していることが見出され (Lonsdale 1977; Corliss et al. 1979), それまでの生物学の常識を覆すような事 実が次々と発見されるに至った（Van Dover 2000 の総説参 照). 最む人々が鳘いたことは, シロウリガイ属 Calyptogena や八オリムシ Riftia, さらにシンカイヒバリガイ属 Bathymodiolus などの消化管が退化的であることから, 生 命活動に必要なエネルギーをどのような生化学的な過程で 得ているのであろうかということであった。この特異な生 態系は太陽光にほとんど依存せず, 微生物による化学合成 によって生命活動に必要なエネルギーの一次生産が行われ ていることが明らかにされ，化学合成生物群集之呼ばれる に至った (Jannash \& Wirsen 1979). 現在, わが国は火山活 動の盛んな地㪍变動の激しいアジア大陸東岸に位置するた めに, 周辺海域に多くの化学合成生物群集が分布している という好条件にあり,この方面の先駆的な研究が展開され ている.

この総説の目的は, 深海化学合成生物群集におけるエネ ルギーの流れを明らかにするために, 鳃や栄養体に硫黄酸 化細菌, あるいはメ夕ン酸化細菌のいずれか, あるいは両 者を共生させ, これらの細菌が生産する有機物を使って生 命活動を展開している生物,「独立栄養動物」について, 軟 体部を構成する主要な元素である, 炭素, 窒素および硫黄 （親生元素と総称する）の安定同位体組成をトレーサーと して行われた既往の研究を総括することである. 化学合成 生物群集のエネルギー源となっている硫化水素やメ夕ンの 起源は, 地球上の多様なテクトニックスと密接に関倸して いるから，生物試料之同時に，あるいは別途分析された， これらガス状物質の安定同位体組成のデー夕を並列し, 相 互の因果関係について理解を深めようと考えた.

\section{1. 化学合成生物のエネルギー源}

還元型化学種は酸化型に変換される(「燃焼」を意味す る）とエネルギーが発生する.ここで,「独立栄養動物」が 利用可能な還元型化学種としては, 硫化水素およびメタン である。独立栄養細菌の中には，遊離の形態で，たとえば $\mathrm{Fe}^{2+}, \mathrm{Mn}^{2+}$ およびアンモ二アなどを酸化して, その際発 生する化学エネルギーを生命活動に利用する微生物群が存 在するが, 動物の体内に共生している例はこれまでには知 られていない.

硫化水素 $\left(\mathrm{H}_{2} \mathrm{~S}\right)$ を構成する硫黄は, 酸化状態が II であ り，鰓の細胞内に共生する硫黄酸化細菌によって取り込ま れて, 順次, 元愫状硫黄 ( $\mathbf{S}^{0}$, 酸化状態, ゼ口), 千才硫酸 $\left(\mathrm{S}_{2} \mathrm{O}_{3}{ }^{2-}\right.$, 酸化状態, $\left.\mathrm{IV}^{+}\right)$, 最終的に硫酸 $\left(\mathrm{SO}_{4}{ }^{2-}\right.$, 酸化状 態, $\mathrm{VI}^{+}$) 入と酸化される, この酸化の進行に伴って放出さ れるエネルギーは, ATPやNADPH といった化学エネル
ギーの形で共生細菌と宿主の生命活動を支える. 同時に, 環境水中の重炭酸イオンを還元し，アンモ二アの存在下 で，アミノ酸, ペプチド，さらにはたんぱく質などの生体 高分子を合成する。二枚貝のある種のものは, 硫化水素の 中間代謝産物である元素状の硫黄が鰓に顕著に, たとえ ぱ, 鰓の乾物重量として $30 \%$ 近くも蓄積している例が観 察される (Mizota \& Maki 1998).

メタンは, 鰓中のメタン酸化細菌に取り込まれた後, ア ルデヒドを経由して最終的には炭酸ガスと水にまで酸化さ れ, 排出される。メタンはエネルギー源であるのと同時に, 生体高分子の主要な構成元素である骨格炭素にも取り込ま れる二重の働きをしている.

硫化水素やメ夕ンが化学合成生物群集のエネルギー源で あるため,これらの成分が通常の海水に含まれる量に比へ て格段に濃度が高い地域に限っての及, 化学合成生物群集 が成立する.これまでに知られている生息環境としては, 地下深部からのマグマの湧き出し口となっている中央海嶺 や島弧の火山前線㧍よび背弧海盆の拡大軸における海底火 山活動に伴う熱水の噴出孔周辺, 海洋プレートの収束に 伴って压密された堆積物から間隙水が较り出されるよう な, テクトニクス的に活動的な地域, 海底からの石油やメ タンハイドレートの分解産物の湧出, 高塩濃度水 (brine) の湧出がある (Van Dover 2000).これらに加えて, やや特 異的であるが, 海洋プレートの沈込み帯・前弧の蛇紋岩 「泥火山」に伴う生物群集の研究例 (Yamanaka \& Mizota $e t$ al. 2003b) をこの総説では取り上げる.

\section{2. 化学合成生物と安定同位体 地球化学の接点}

海洋の植物プランクトンなどによって生成される有機物 の炭素同位体組成は，おおよそ -25 加ら $-20 \%$ 程度 (Paull et al. 1985) の範囲に集中し，この值は $\mathrm{C}_{4}$ 植物を除 いた陸上高等植物や, 土壤に含まれる有機物の平均的な炭 素同位体組成 (ともに約 $-25 \%$ ) より ${ }^{13} \mathrm{C}$ に富化している. このことを受け, 海底堆積物中の有機物の炭素同位体組成 は, 海岸からの距離, すなわち陸上有機物の寄与の程度が 低くなるとともに ${ }^{13} \mathrm{C}$ に富化し， $-26 \sim-24 \%$ から $-20 \%$ まで増加する (Sackett \& Thompson 1963). 従属栄養性のべ ントスの炭素同位体組成も，この变化を反映し，変動する と考えら机る.

メタン $\left(\mathrm{CH}_{4}\right)$ の最も一般的な生成機構は, 常温近傍でメ 夕ン生成細菌によって有機化合物の還元的な最終分解産物 として, 酷酸のメチル基への水素の付加反応, 扰よび $\mathrm{CO}_{2}$ の還元反応によって生成する (Schoell 1988). このメタン は, 炭素同位体組成 $\left(\delta^{13} \mathrm{C}=-45 \%\right.$ 以下) が低いことに よって特徴づけられている (Schoell 1988). 一方, 地下深く 埋没した有機物は, 地温勾配による温度の上昇に伴って一 部が分解し, 熱分解性メタンを生ずる，その炭素同位体組 
成は, $\delta^{13} \mathrm{C}$ 值が -40 から $-25 \%$ 付近にある. 海洋地殻の オフィオライトおよび東太平洋海膨に伴うマグマ起源のメ タンの炭素同位体組成は著しく重く, $\delta^{13} \mathrm{C}$ 值が -20 から -10\%。の範囲にある (Schoell 1988).

硫黄は海産動物類の軟体部に通常乾物割合として 0.5 から 1\% 前後含まれ, 炭素, 水素, 酸素, 窒素に次いで 5 番目に多く含まれる。一次生産者は海水中の硫酸イオンを 硫黄栄養源とし，その硫黄安定同位体組成は均質で，重く +21\%o を示す (Rees et al. 1978). 海水硫酸イオンは, 食物 連鎖網を通して，捕食する者である海産動物類の体構成成 分へと継承される。ここで，硫酸イオンは含硫了ミ/酸や スルホン酸基として生体成分の合成に取り込まれる。この 間の硫黄栄誉の動力学的な同位体分別は，最大でも5\% 程 度と見積もられ，栄银段階の䢖いに対応した硫黄の同位体 分別は認められていない (Fry 1983, 1988; Peterson \& Howarth 1987).

硫化水素は，熱水活動によって海底に放出されるマグマ 起源むしくは地下の岩石（主に火山岩）之熱水の相互作用 によって生じるすのと，硫酸僄元菌によって有機物などを 電子供与体とした海水の硫酸還元によって生じる微生物起 源のものに大きく大別される（酒井・松久 1996）。 マグマ や火山岩に由来する硫化水素の硫黄同位体組成は最大の変 動籍囲を取ってる， $-5 \sim+10 \% 0 の \delta^{34} \mathrm{~S}$ 值を持つ. 微生物 起源のものは，硫酸還元の際に大きな同位体分別が生じる ことから，非常に軽い值(0\%0より有意に小さく，時にー40\% 以下となる）が還元的な海底堆積物中で認められるが, 硫 酸の量が限られる閉鎖的な環境では，值は大きくなる，硫 化水素の多い還元的な堆積物に生息するベントスの一部 は，硫酸逼元細菌や硫化水素を酸化する硫黄酸化細菌を補 食するなどの方法で软体部に同化し，微生物起源の軽い硫 黄同位体組成を示す (Yamanaka \& Shimoyama et al. 2000; Yamanaka \& Mizota et al. 2003c).

窒素は海洋表居の生物旦を制限する栄養の一つであり， 特に硝酸イオンとアンモニアは主要な栄養源である。硝酸 イオンやアンモニアは陸上で行われているように窒素ガス $\left(\mathrm{N}_{2}\right)$ を固定する生物の存在や陸上からの直接の流入，動 物プランクトンによる排出やプランクトンの臬骸の微生物 分解産物として供給され，窒素の同位体組成は複雑な分布 を示す (酒井・松久 1996). 海洋の浮遊性プランクトンの 窒素同位体組成の平均的な值は, +2〜 +8\%, 動物プラン クトンでは $+8 \sim+15 \%$ と，順次栄養段階の上昇に伴って 重くなる (Paull et al. 1985)。 また，海洋の堆積有機物の窒 素同位体組成は，給源窒素の無機化，有機化，アンモ二ア 化，脱窒過程などの複雑な過程を経て，おおよそ+5\% 前 後に収敛する。しかしながら，化学合成生物群集の一次生 産を担う微生物の窒素举食源としては，その還元的な環境 からアンモニアが主要な化学種と考えられるほかに，低分 子のアミノ酸す候補となりうる。取り込まれたアンモニア はアミドペプチドを経由してたんぱく質の棲成に使われ
る.

以上のように，生物の親生元素の安定同位体組成は，栄 養段階によって変化する窒素を除けば，慨となる生物の安 定同位体組成を引き継ぐ，化学合成生物の場合，利用する エネルギー源となるメタンや硫化水素の安定同位体組成が 軟体部の安定同位体組成を規制していると考えられ，多様 な安定同位体組成が，化学合成生物のエネルギー源を推定 する上で有用である。

\section{3. 親生元素の安定同位体組成からみた ベントスのエネルギー獾得機構}

Table 1 および Table 2 は、これまでに共生細菌を持つ動 物の安定同位体組成をまとめたものである。これらの表に おいて，試料は，採集地に基づいて次のような順序にまと めてある．まず，わが国に近い，北西太平洋の高緯度域か ら低緯度熱帯域，西部南太平洋，インド洋，ついで東太平 洋の高緯度加東部南太平洋に功て, さらに北大西洋加 ら熱帯，メキシコ湾，最後にペルー沖へと配列した。これ は，これら生物の安定同位体組成が，種ごとに特徵を持つ わけではなく，生育環境，すなわち以下で解説されるよう にテクトニックな背景によって規制されているためであ る.

3-1. 硫黄酸化梱菌を共生させているベントス（シンカイ ヒパリガイルニ枚貝を除く）の安定同位体組成

(Table 1)

Table 1 に, シンカイヒバリガイ属 Bathymodiolus を除く 二枚貝類，腹足類および八オリムシ類の，Table 2 には，シ ンカイヒバリガイ属の炭素, 室素および硫黄の安定同位体 組成と,これら動物が生息している環境（粘土質堆積物, 冷湧水および熱水試料) 中の硫化物態硫黄, メタン態炭素 およびアンモニア態窒素の安定同位体組成をまとめた，軟 体部を構成する親生元素の中で，ここで取り上げた三っの 元素については，炭素同位体組成の測定デー夕数が最も多 く，っいで窒素，最後に硫黄と続いている，特定の生物種 について,これら 3 元素の測定値が揃っている例は少な い、さらに，これらの動物と生息環境中のエネルギー源を 一つのセットとして採取・分析された例は，極限られてい る.

Table 1 に揭げた動物式料の锶や栄養体には共生細菌と しては硫黄酸化細菌のみであることが，乾燥鰓試料の高い 硫黄含量 $(>1 \%)$, 鰓内の元素状硫黄顆粒の存在, 硫化水 素の酸化に関与している醉素群の比活性測定, 16S rRNA の塩基配列の解析および鰓の超切片を用いた共生細菌の細 胞膜の透過型電子顕微鏡による形態の観察などを組み合わ せた結果から判断されている (Nelson \& Fisher 1995).

3-1-1. 炭秦同位体組成

ベントスの鰓や栄養体に共生している硫黄酸化細菌は， 


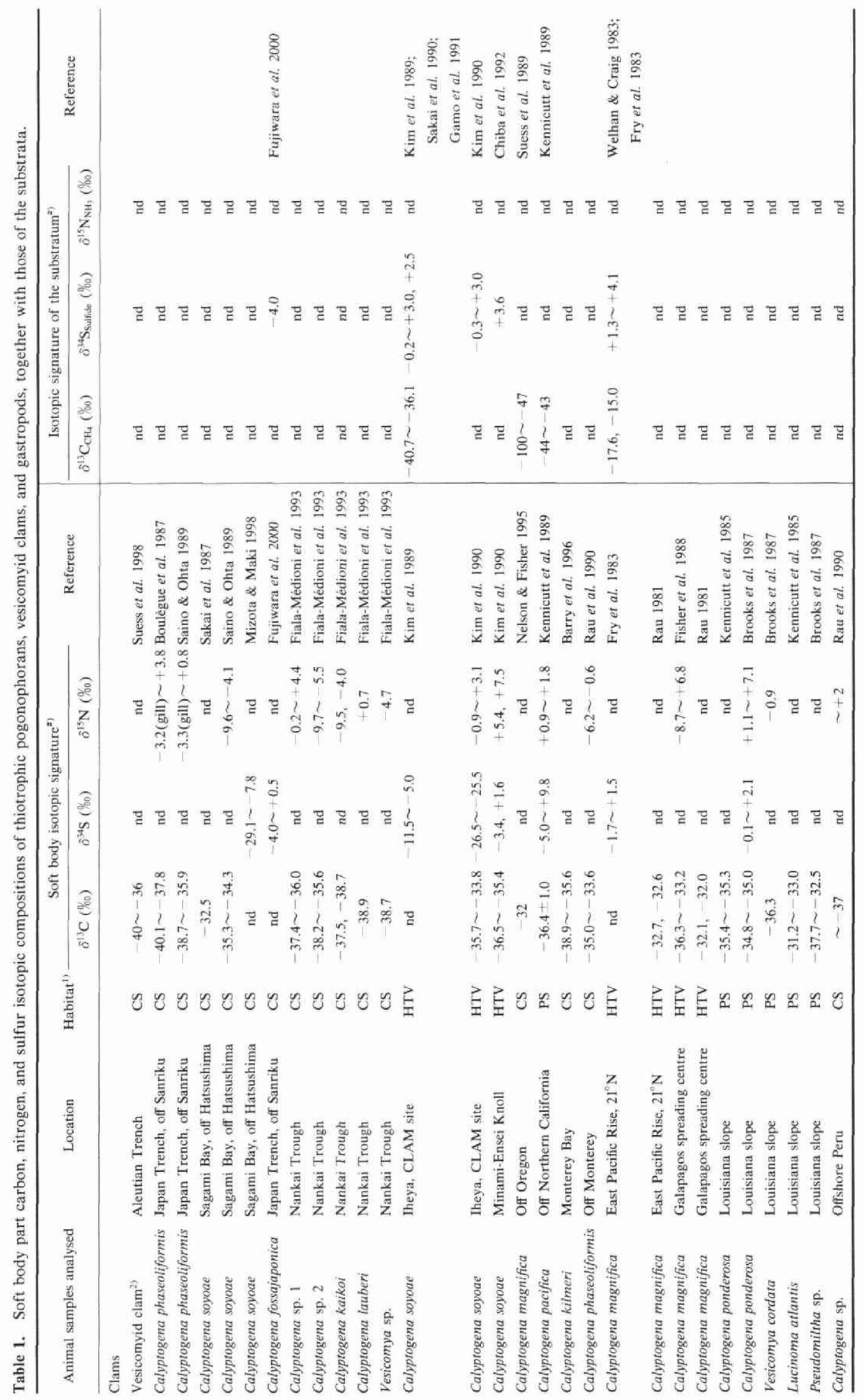




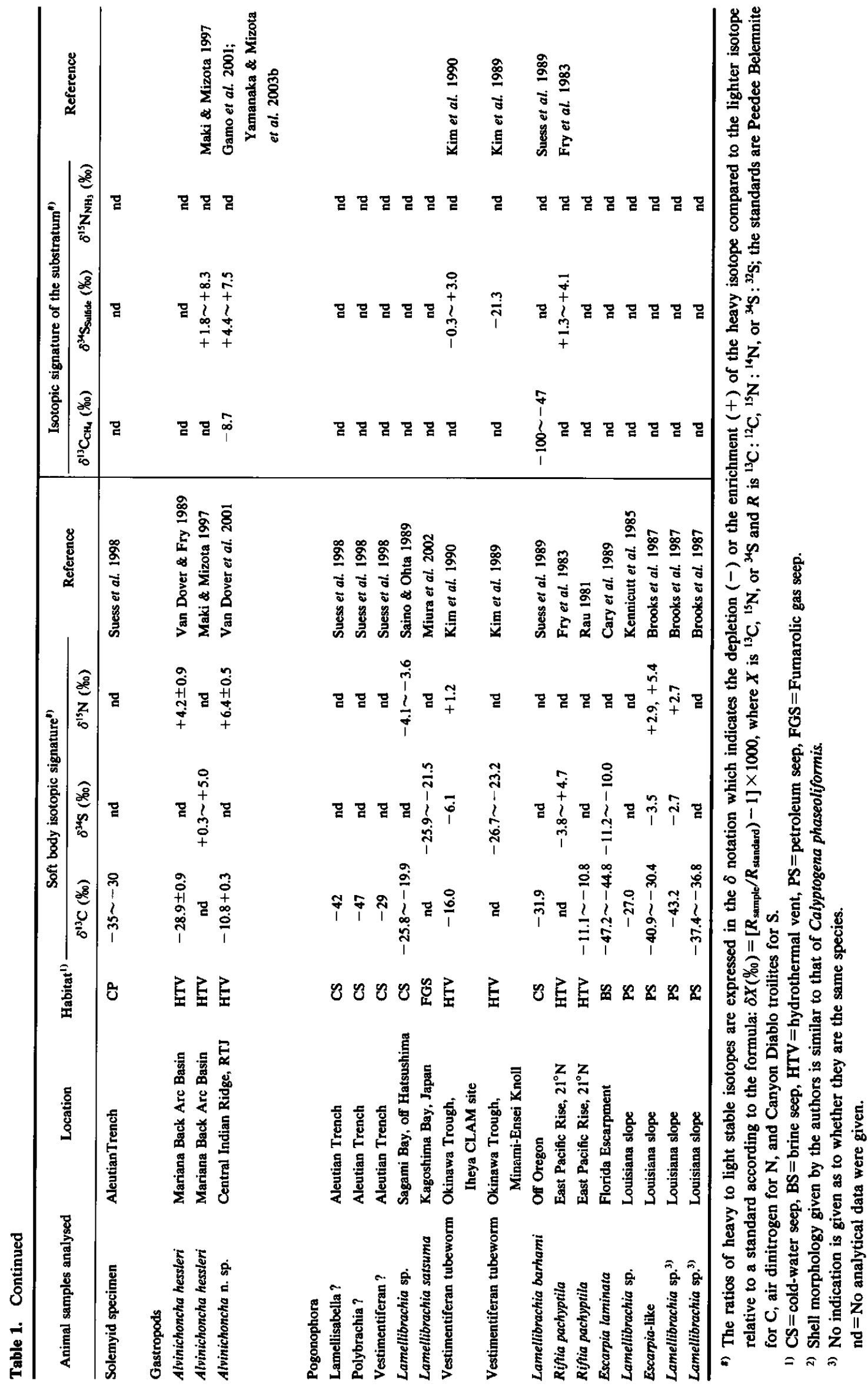




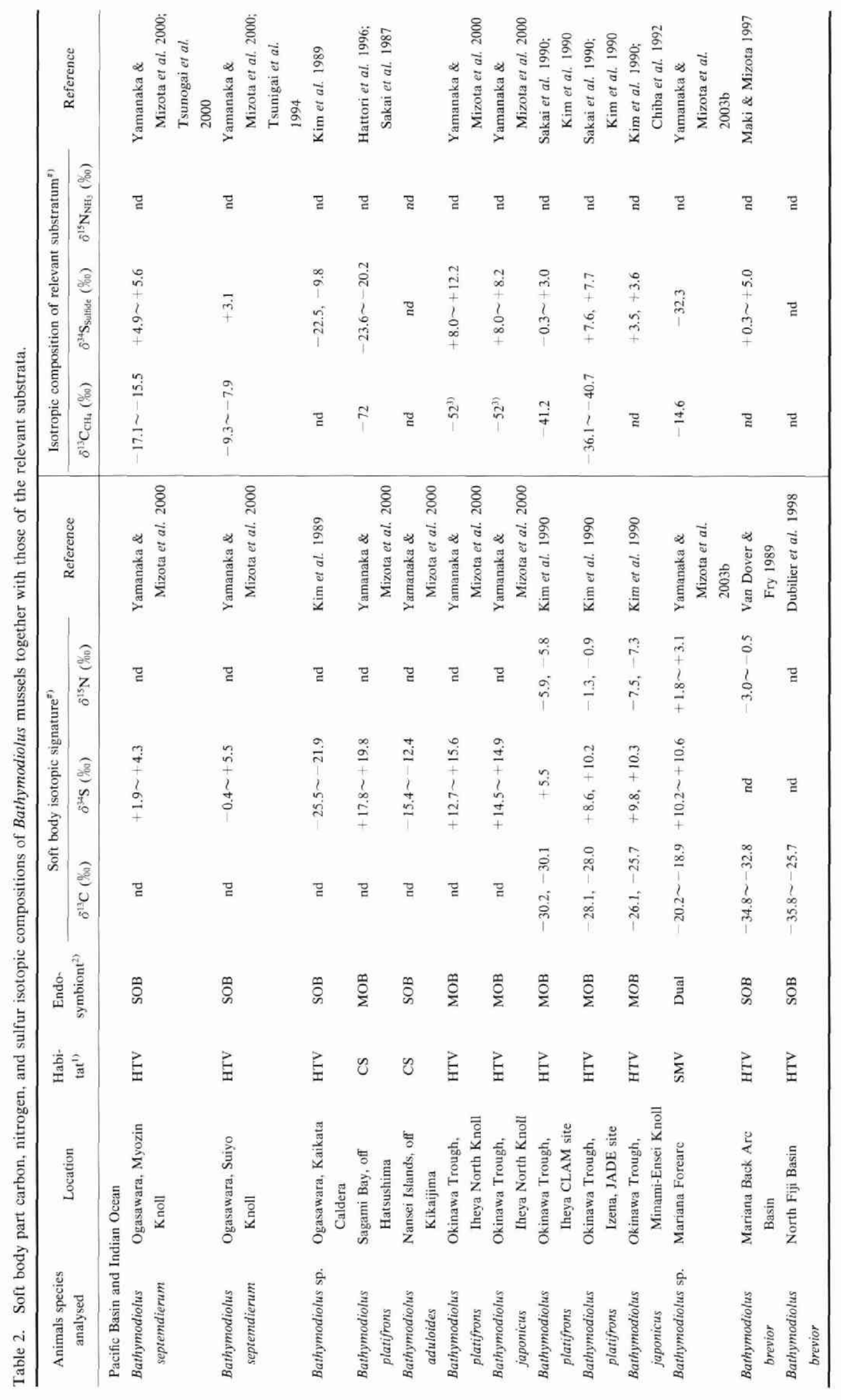




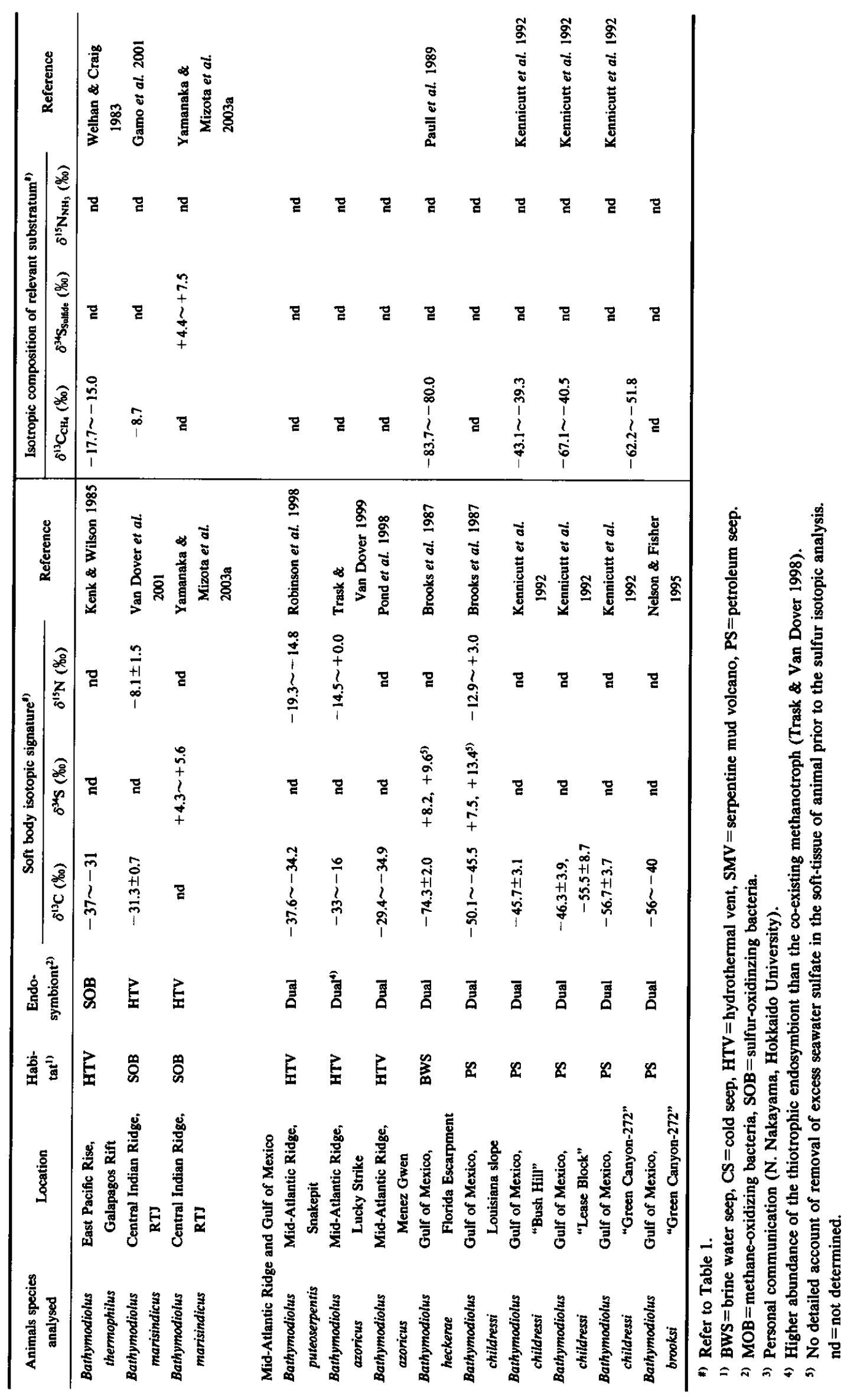


宿主が環境から取り込んだ硫化水素を受け取り，元素状硫 黄, チ才硫酸, さらに硫酸に順次酸化させ, その過程で生 じる化学エネルギーを用いて Ribulose-1,5-biphosphate carboxylase/oxygenase (以下 Rubisco と略称する)による炭 酸固定を行う (Nelson \& Fisher 1995). 天然および人工培養 条件下での, 硫黄酸化細菌による無機炭素の取り込みを観 察した既往の解析結果によ扎は, 炭酸固定に伴う炭素同位 体の分別值（元の無機炭素源の炭素同位体組成と生体高分 子に取り込まれた形態の炭素化合物の炭素同位体組成の差 で表される) は〜 - 35\% であることが知られている (Ruby et al. 1987). 硫黄酸化細菌老鰓に共生させている動物群の 炭素同位体組成は, この - 35\% 在中心として, 軽い側と重 い側に, 恐らくは生息環境周辺における給源溶存重炭酸イ オンの炭素同位体組成の地域的な変動を反映して,それぞ れお抢よそ5\% 前後の変動範囲か認められる (Table 1).

これに対して, マリアナ背弧海盆扰よびインド洋中央海 嶺・ロドリゲス三重点の熱水噴出孔周辺から採取された 2 種の Alvinichoncha 属腹足類の炭素同位体組成（-29\%。 以 上）は, 前述の炭素同位体組成の值に比べて, 有意に重い 側にある (Van Dover \& Fry 1989; Van Dover et al. 2001). この重い同位体組成は，地下深部で生成した炭素同位体組 成の高いマグマ性メタンの積極的な取り込み（二硫黄酸化 細菌に加えて, メタン酸化細菌の共生), 異なる型の炭酸還 元酵素 (Type II Rubisco; 基質炭酸イオンとの炭素同位体 分別が通常に存在するI型より小さい型）および腹足類の 生息環境水に溶存した重炭酸イオン濃度が低いこと（低い $\mathrm{CO}_{2}$ 濃度環境下では炭酸固定に伴う生物学的な同位体分 別の効果が発現しない現象を指す)，㤎提案されている (Van Dover et al. 2001). マリアナ背弧海盆のAlvinichoncha hessleriについては, メタンの直接酸化に関与しうる生体内 の酸化醅素が存在しないこと, 鰓・超切片の透過型電子顕 微鏡観察によって,メ夕ン酸化細菌に固有の細胞膜組織を 持つ共生細菌が積極的には同定されていないことが確認さ れており (Stein et al. 1988), 最初の解粕は否定されるよう にあみえる. しかし, Endow \& Ohta (1989) は, 硫黄酸化 細菌の存在に加えて, メタン酸化細菌に類似した膜構造を 持つ, むう 1 種の共生細菌 (membrane-stacked bacteria) の 存在が示されている. 共生細菌のうち,この特異な形態を もつ細菌を電顕写真上で計数したところ, 一定面積内に認 めら机る硫黄酸化細菌数の $10 \%$ ，あるいはそれ以下で あった。したがって，ここで見出された細菌が仮にすべて メタン酸化細菌であったとし，この熱水系で供給されるメ タンと硫化水素がマグマ起源であるとするならば $\left(\delta^{13} \mathrm{C}=\right.$ $-10 \sim-20 \% 0, \delta^{34} \mathrm{~S}=0 \sim+5 \%$ ), 得られている炭素同位体 組成 $(-28.9 \pm 0.9 \%)$ (Van Dover \& Fry 1989) および後述 の硫黄同位体組成 $(+0.3 \sim+5.0 \%)$ (牧・溝田 1997) は無 理なく説明が可能な範囲にある.インド洋のAlvinichoncha を含めて, こ㧈ら 2 種の腹足類の炭素栄養の特異性の解析 のためには, 共生細菌の分子生物学的な特徴付けなど, 今
後の分析が必要とされる.

Pogonophora (有殨動物) の炭素同位体組成は, 軽いむの では $-42 \%$ から, 重いものでは $-11 \%$ までの大きな炭素 同位体組成変動を示した (Table 1)。このうちで，八オリム シ類については, Escarpia 属が, -47 から $-30 \%$ にわ たっての最も軽い炭素同位体組成傾向を示した (Brooks et al. 1987; Cary et al. 1989). Escarpia 属は, メキシコ湾内の 高塩分濃度水や石油の㴊出地帯加ら得られており, 海水に 溶存する重炭酸以外に, 俥整い炭素同位体組成を持つメタン を摄取していることが考えられる，それらの生息地のテク トニクスから, 海底下深部での埋没有機物の熱分解に起源 するメタン $\left(\delta^{13} \mathrm{C}=-40 \%\right.$ 付近 $)$ およびメ夕ン生成微生物 起源の軽いメタン炭素 $\left(\delta^{13} \mathrm{C}=-70 \%\right.$ 付近）の取り込み (硫黄酸化細菌に加えて, メ夕ン酸化細菌の共生の可能性) によることも解釈できる。しかし，Florida Escarpment か ら採取された Escarpia laminata（trophosome および vestimentum）は methanol dehydrogenase の活性を検出できな い(Cary et al. 1989)。これらの事実加ら, メ夕ン酸化細菌 の共生の可能性は極めて低く, 軽い炭素を固定する機構は 不詳である。

Lamellibrachia 属も軽い種 $(-43 \%)$ 加重い種 $(-20 \%)$ まで,かなりの変動を示した (Table 1).このうち, 地理的に 著しく隔離されている相模湾初島沖の冷湧水地域と, メキ シコ湾の石油涌出地域からのハォリムシ類は抢互いに類似 した炭素同位体組成を示した (Kennicutt et al. 1985; Saino \& Ohta 1989). また, 沖縄トラフ伊平屋海嶺の八オリムシ もかなり重い炭素同位体組成によって特徴付けられる (Kim et al. 1990). メキシコ湾 Louisiana slope の Lamellibrachia 属うち, Upper Texas slope からのものは, 硫黄酸化 細菌を体内共生させている動物の炭素同位体組成とほぼ調 和する組成群 $\left(\delta^{13} \mathrm{C}=-37.4 \sim-36.8 \%\right.$ ) 皂す (Brooks et al. 1987). これよりも数\% 軽い Lamellibrachia 属 $(-43.2 \%$ ) は, 異なる地点から採取されている。ここで, 最初の試料 (硫黄酸化細菌が共生している) にはメタン酸化細菌共生 が存在しないことが証明されている (Brooks et al. 1987).

一方, 軽い炭素同位体組成を示す Lamellibrachia 属につい ては, メタン酸化菌の共生は確証できないが, 存在を否定 するためのデー夕は得られていない.

東太平洋海膨北緯 21 度の熱水噴出孔周辺に生息するガ ラパコスハォリムシ Riftia pachyptila の炭素同位体組成 $(-11 \%$ ) は, これまで分析された八オリムシ類の中で最む ${ }^{13} \mathrm{C}$ に富化していた (Rau 1981)。ここで, 重炭酸の取り込 みに関与する酵素の炭素同位体分別が小さいことが推察 されているが, 確証は得られていない (Nelson \& Fisher 1995).

以上のように, 冷湧水帯環境の中で, およそー40\%。り 俥呈い炭素同位体組成を示すハオリムシ類の栄養体には硫黄 酸化細菌とともに, メ夕ン酸化細菌の共生の可能性が推察 され，今後，共生細菌の分子情報抢よび透過型電子顕微鏡 
による直接観察などが望まれる.

\section{3-1-2. 硫责同位体組成}

硫黄酸化細菌を共生させているべントスのうち, 東太 平洋海膨北緯 21 度域の熱水噴出孔周辺からのガラパゴス シロウリガイ Calyptogena magnifica, ガラパゴスハオリム シおよびマリアナ背弧海盆の Alvinichoncha 属腹足類の硫 黄同位体組成は, 生息環境の熱水あるいはチムニー硫化鉱 物に含まれるマグマ起源硫黄 (0\% 前後) の同位体組成と ほぼ調和的であり（Fry et al. 1983; 牧・满田, 1997; Yamanaka \& Mizota et al. 2003a), これらの硫黄栄锒の主体が熱 水活動由来の還元型硫黄であることを示唆する. 一方, 日 本海洅三陸沖のナラクシロウリガイ Calyptogena fossajaponica (Fujiwara et al. 2000), 相模湾初島沖のシロウリガイ Calyptogena soyoae (Mizota \& Maki 1998) および鹿児島湾 奥部の「たぎり」からのサッマハオリムシ Lamellibrachia satsuma (Miura et al. 2002) の硫黄同位体組成は, いずれる 生息域直下の堆積物に含まれる海水硫酸イオンの微生物還 元による軽い値に対応した ( $0 \%$ 以下).

ハオリムシ類と生息㻴境の熱水や堆積物に含まれる硫化 物態硫黄の同位体組成を相互に対応させながら解析した研 究例は限られている (Table 3). サッマハオリムシの軽い 硫黄同位体組成から，サッマハオリムシは，その細長い莦 の下部を堆積物に差し込み, 硫黄栄養の大部分を堆積物中 の硫化物から摂取していることが推察される. 溶存硫化物 硫黄の体組織への取り込みに際しては, ごくわずかの硫黄 同位体分別しか钼察されていないことが温泉水に生息する 硫黄酸化細菌の集合体（バクテリアマット）で確認されて いる (Mizota \& Maki 1999). そこでサッマハオリムシの軟 体部に含まれている硫黄について, 堆榬物中の硫化物 $\left(\delta^{34} \mathrm{~S}=-30 \%\right)$ と海水硫酸イオン $\left(\delta^{34} \mathrm{~S}=+21 \%_{0}\right)$ の 2 成分 混合系モデルから計算すると, 硫化物硫黄の奇与割合は, 80 ないし 90\%程度と見積もられる。これは, サッマハオリム シの硫黄栄養は火山性 $\left(\delta^{34} \mathrm{~S}=0 \sim+5 \%\right)$ ではなく, 生息地 直下の堆積物中の微生物活動に由来することを示唆する.
微生物起源の軽い硫化物硫黄を取り込んだ例のほかに, 石油, メキシコ湾ルイジアナ沖の大陸棚およびフロリダ沖 の海底急崖, 高塩䈨度水の涌出地帯からは, やや傾向が異 なるシロウリガイ属やハオリムシ類についての分析結果が 報告されている (Brooks et al. 1987; Cary et al. 1989; Kennicutt et al. 1989). その硫黄同位体組成は, 海水硫酸と硫酸 還元菌起源の硫化物硫黄との言わば「中途半端」な領域に ある. しかし, 海水硫酸イオンの值 $\left(\delta^{34} \mathrm{~S}=+21 \% 0\right)$ に比較 すると, いずれの試料软組織も0\%。近傍か, あるいは明暸 に $0 \%$ より負側にあることから, 軽い還元型硫黄が、これ ら生物の組織に積極的に取り込まれているのは事実であ る.

\section{3-1-3. 䆟菜同位体組成}

通常の海産動物の窒卖同位体組成は，ほとんどが, 大気 の窒素同位体組成 $\left(\delta^{15} \mathrm{~N}=0 \%\right.$ ) よりはプラス側に位置して いる. そして，窒素の同位体組成は食物連鎖網と密接に関 連しており，栄養段階が一つ上昇するにつれて窒素同位体 組成は，平均して 3.4\% 上昇することが経験的に知られて いる (Wada \& Minagawa 1984).

シロウリガイ属およびハオリムシ類の室素同位体組成の 値 $\left(\delta^{15} \mathrm{~N}\right)$ は，熱水噴出孔に生息する種では 0 より明瞕に プラス側に偏るようにみえ，これらの生物が生息する環境 のテクトニックな背景と密接に関係しているかもしれない (Table 1).これら硫黄酸化細菌を体内共生している動物の 一次的な窒素栄養源は，宿主の生息域が熱水噴出孔および 冷涌水帯の還元的な環境に極限されていることから，化学 種としてアンモニアが主要な無機態窒素と推察される.こ のテクトニックな背景と関連したアンモニア態窒素の窒素 同位体組成の変動が, 直接に宿主動物の空素同位体組成変 動に反映されていると解釈されるが, 生息環境中のアンモ ニアの窒素同位体組成の報告はない.

\section{3-2. シンカイヒパリガイ盾二故貝の安定同位体組成} シンカイヒバリガイ属二枚貝 (Table 2) は, 硫黄酸化細

Table 3. Sulfur isotope composition of different soft tissues of a tubeworm, Lamellibrachia satsuma, and associated sulfide-sulfur in the sea bottom sediments'.

\begin{tabular}{|c|c|c|c|c|c|c|c|c|}
\hline \multirow{2}{*}{$\begin{array}{l}\text { Dolphin 3K } \\
\text { dive Nos. }\end{array}$} & \multirow{2}{*}{$\begin{array}{l}\text { Water depth } \\
\text { (m) }\end{array}$} & \multicolumn{2}{|c|}{ Sampling location } & \multicolumn{3}{|c|}{ Tubeworm } & \multicolumn{2}{|c|}{ Associated sediment sulfide } \\
\hline & & Longitude (E) & Latitude (N) & Tissue & $S(\%)^{3)}$ & $\delta^{34} \mathrm{~S}(\% 0)$ & $S(p p m)^{4)}$ & $\delta^{34} S(\%)$ \\
\hline \multirow[t]{2}{*}{342} & 99 & $130^{\circ} 48.189^{\prime}$ & $31^{\circ} 39.546^{\prime}$ & Vestimentum & 1.1 & -21.8 & $1,100^{5)}$ & -27.1 \\
\hline & & & & Trophosome & 3.3 & -20.7 & & \\
\hline \multirow[t]{2}{*}{344} & 94 & $130^{\circ} 48.171^{\prime}$ & $31^{\circ} 39.521^{\prime}$ & Vestimentum & 1.0 & -20.8 & 2,400 & -29.6 \\
\hline & & & & Trophosome & 5.2 & -21.3 & & \\
\hline 340 & 90 & $130^{\circ} 48.197^{\prime}$ & $31^{\circ} 39.544^{\prime}$ & & & & 1,567 & -33.6 \\
\hline 341 & 209 & $130^{\circ} 46.432^{\prime}$ & $31^{\circ} 39.544^{\prime}$ & & & & & $+6.5^{6)}$ \\
\hline
\end{tabular}

1) Mizota, C. and T. Yamanaka (unpublished data).

2) Dives were carried out during June, 1997.

3) $105^{\circ} \mathrm{C}$ dry-matter basis.

4) Fresh sediment basis.

5) Collected by dive 3K-345.

6) Hydrogen sulfide recovered from fumarolic gas sample. 
菌を鰓に共生させているもののほかに, メタン酸化細菌を 単独で, あるいは硫黄酸化細菌と共に二重に共生させてい るものが知られている (Nelson \& Fisher 1995). メ夕ン酸 化細菌の鰓共生のための直接的な証拠としては, 硫黄酸化 細菌の場合の上うに 16S rRNA の塩基配列の決定に加え て,メタンの酸化に関与する methanol dehydrogenase の比 活性測定书よび鰓・超切片の透過型電子顕微鏡による特異 な膜構造の視認がある (Nelson \& Fisher 1995). シンカイ ヒバリガイ属は，シロウリガイ類 Calyptogena やハオリム シ類 Riftia のように消化器官が完全には退化せず，濾過摄 食能を維持していると考えられている (Van Dover 2000).

\section{3-2-1. 炭素同位体組成}

硫黄酸化細菌のみ共生させるシンカイヒバリガイ属の 炭素同位体組成は，ほぼ $-35 \pm 5 \%$ 付近の範囲にあり，海 水に溶存している重炭酸 $\left(\delta^{13} \mathrm{C}=0 \%\right.$ ) が Rubisco を触媒上 して取り込まれていることが推察される (Table 2). しか し, メキシコ湾の石油や高濃度塩水の涌出地帯加らの数種 については,この值より著しく軽い,たとえばー74\% にあ 達するような $\delta^{13} \mathrm{C}$ 值が知られている (Brooks et al. 1987; Kennicutt et al. 1992; Nelson \& Fisher 1995). このように ${ }^{13} \mathrm{C}$ に枯渴した動物試料は, メタン生成微生物起源の軽い メタンを同化した結果と解釉され (Paull et al. 1989), 鰓の 共生細菌種や methanol dehydrogenase 活性の測定の結果と 屯矛盾しない (Nelson \& Fisher 1995).

大西洋中央海嶺 (MAR) 加らの二重共生を持つ Bathymodiolus puteoserpentis 之B. azoricus は, 硫黄酸化細菌を持 つ種之類似の炭素同位体組成を持古, 環境水からのメタン 栄養の積極的な取り込みは見えない，これらは熱水に含ま れるメタンが，マグマ起源で重い炭素同位体組成を持って いるためか (Welhan \& Craig 1983), あるいは種ごとに異 なったメタンの特異な体内代謝系のために，同位体標識の 識別が結果的に明瞭ではなくなったものと解釈される。

MAR の Lucky Strike 熱水噴出地点から採取した B. azoricus の鰓については, 超切片・透過型電子顕微鏡観察によ り, 硫黄酸化細菌とメタン酸化細菌の分布割合が計測され ている (Trask \& Van Dover 1999). それによると, メタン 酸化細菌に比較して硫黄酸化細菌の割合は 2 桁ほど高い。 このような高い硫黄酸化細菌の割合は, このB. azoricus が メタンをエネルギー源としてほとんど利用していないこと を示唆し, 同位体的にもメ夕ン酸化細菌の寄与が現れない と考えられる.

マリアナ前弧域にある蛇紋岩の泥火山 (South Chamorro Seamount) の頂上に生息する未記載種の炭素同位体組成 は, 著しく ${ }^{13} \mathrm{C}$ に富んでいる (Yamanaka \& Mizota et al. 2003b).この重い炭素は, かんらん石の変質に伴って生成 する特異な炭素同位体組成を持った非生物起源のメタン $\left(\delta^{13} \mathrm{C}=-14.6 \%\right)$ の取り込みに由来するものと解釉されて いる.

\section{3-2-2. 硫黄同位体組成}

硫黄同位体組成は, 給源硫黄栄養の同位体組成変動を反 映して, かなりの多梯性が認められる (Table 2). ここで, 硫黄酸化細菌を唯一の共生細菌とする種のうち, 熱水噴出 孔の周辺からの試料は, マグマ起源の硫化物態硫黄の積極 的な取り込みを反映し，ほぼ 0 付近から $+6 \% 0$ の $\delta^{34} \mathrm{~S}$ 值を 示した. 一方, $-17 \%$ 以下の軽い硫黄で特徵付けられる 2 種か，鹿児島喜界島沖の冷湧水帯 (Yamanaka \& Mizota et al. 2000) や小笠原諸島海域海形海山の温水湧水地帯 (Kim et al. 1989) から報告されている. 海形海山の例は, 玄武岩 質砕屑物 (マグマ由来の物質) が卓越する環境においても, 硫酸還元菌の生育に好適な条件が整えば, 微生物起源の硫 化物硫黄がベントスの硫黄栄養源になることを示唆してい る.

メタン酸化細菌のみ在共生させる種の梳黄栄養源として は，海水硫酸イオン $\left(\delta^{34} \mathrm{~S}=+21 \% 0\right)$ であることが予測され る. 相模湾初島沖の冷湧水帯や沖縄卜ラフ伊平屋北部海丘 熱水噴出孔周辺からのへイトウシンカイヒバリガイB. platifrons, およびシンカイヒバリガイ B. japonicus の $\delta^{34} \mathrm{~S}$ 值 は, 一般的な海棲動物の值に類似して, +13 から $+16 \%$ の範囲にある (Yamanaka \& Shimoyama et al. 2000; Yamanaka \& Mizota et al. 2000). ここで, 海水硫酸イオンの取り 込みに伴う動力学的な, 負の同位体効果（おおよそ $-5 \%$ 程度）を考慮すれば, これらの測定値は, 妥当な值である.

沖縄トラフの伊平屋 CLAM 地点, 伊是名 JADE 地点お よび南奄西海丘から採取された B. platifrons および B. japonicus の硫黄同位体組成は, +6 から $+10 \%$ の間にあり (金ら 1990), 相模湾初島沖や伊平屋北部海丘の同種の値に 比へて負側にある，共生細菌は宿主の種に固有であり，親 から子へと「垂直伝達」(vertical transmission)されること が知られて抢り (Nelson \& Fisher 1995), メタン酸化細菌 に加えて, 硫黄酸化細菌が共生している可能性（いわゆる 二重共生）は考えにくい.むしろ，この軽い硫黄の給源と しては, 遊離の硫黄酸化細菌菌体を直接滤過摂食する可能 性が考えられる (藤原義弘, 私信)。なお,これら 2 種の炭 素同位体組成は $-30 \%$ 以上の重い値を示しているから, 対応するメタンの炭素同位体はマリアナ蛇紋岩泥火山の例 に似たような，重い「特異な」起源のメタンの取り込みが 推察される。ここに観察された硫黄および炭素同位体組成 異常を矛盾なく説明することは, 生物試料に対応する環境 試料のデータが限られており, 困難である.

硫黄酸化細菌とメ夕ン酸化細菌が二重に共生することが 知られている種（マリアナ前弧域 South Chamorro Seamount, メキシコ湾 Florida Escarpment 扰よび Louisiana slope) の場合は, 重い海水硫酸と海水硫酸イオンの硫酸還 元菌に由来する軽い硫化物態硫黄の値の中間の值を示すこ とから，これらの両成分が硫黄栄養として取り込まれてい るものと考えられる (Yamanaka \& Mizota et al. 2003b). 


\section{3-2-3，車基同位体絪成}

窒素同位体組成は，シロウリガイ属などに比べ， ${ }^{14} \mathrm{~N} に$ 富む (Table 2). とくに, MAR 域からの 2 試料は, ${ }^{15} \mathrm{~N} に$ 枯晹している．この軽い軟体部窒素同位体組成は, 涌出す るアンモニアが ${ }^{15} \mathrm{~N}$ に枯渴した特異な窒素同位体組成を 持っあのか, シンカイヒバリガイ属に取り込まれた後て の, 窒素の体内代謝に伴う同位体分別に起因していると考 えられる.このことについては醳素レベルでの議論が展開 されている (Nelson \& Fisher 1995).

マリアナ前弧の蛇紋岩泥火山から得られた未記載種の窒 素同位体組成 (Yamanaka \& Mizota et al. 2003b) は, 特異 的に重い，蛇紋岩泥火山では，非生物起源のメタンの涌出, メタンの酸化に由来する炭酸塩皮壳の生成と並んで，間隙 水中に高い $\mathrm{NH}_{3}$ が検出されることなどの諸現象が報告さ れており (Mottl 1992)，特異なテクトニクスに支配された 地下生物圈の存在を示唆する (Fujioka et al. 2001; Yamanaka \& Mizota et al. 2003b).

\section{4. 熱水・堆積物間隙水中のアンモニア 態窒素の灌度}

中央海領にみられる海底に噴出した玄武岩の割れ目に発 達する熱水活動域から採取された熱水試料は，玄武岩に含 まれる窒素が極めて少ない（1 ppm N 以下）ことを反映し てアンモニア濃度は極端に低い (Exley et al. 1987). しか し，厚い堆積物を貫通して噴出している，沖縄トラフ背砐 海盆熱水系加らの熱水中のアンモニア浱度は高い傾向にあ る (Table 4). 冷湧水は多くの場合, 海成の堆積物を通過し ているから，熱水試料に比べて2 桁ほど高いアンモ二ア湌 度を示す。これは，堆積物中の有機態窒素が分解されアン モニアとして熱水や冷涌水に取り込まれて涌出しているた めと考えられる。

化学合成生物群集のベントスが示す特異な窒菜同位体組 成変動の解釈ためには，熱水噴出孔熱水や冷湧水中のアン モニアの窒素同位体分析が望まれる。

\section{5. 化学合成生物群集の食物網の解析}

化学合成生物群集の重要な構成ベントスとして, 甲殼類 や多毛類があるが，これらには細菌の細胞内共生は知られ ていないので，他の生物を捕食しているらしい，軟体部の 炭素-窒素同位体組成二軸系のダイアグラムによって MAR およびインド洋中央海镇・ロドリゲス三重点の熱水 噴出孔生態系における食物連鎖が解析されている (Colaço et al. 2002; Van Dover et al. 2002)，ここで，硫黄酸化細菌 やメタン酸化細菌を鰓内に共生させ，一次生産を行うシン カイヒバリガイ属二枚貝が最す低位の段階に，最上位には エビなどの甲殻類が位置し，この間には最大 4 段階の栄養 段階を持つ動物群が識別されている。

\section{6. 要 約}

深海底の熱水噴出孔および冷涌水地帯周辺には，硫化水 素およびメタン，あるいはこれらの両化学種を酸化してエ ネルギーを得る独立栄誉細菌と体内共生し，これらが生産 する有機物に依存するベントスが仏く認められる。これら のエネルギー獲得戦略を明らかにするために，軟体部と， 栄養源である硫化水素, メタンおよびアンモニアの炭素窒素-硫黄同位体組成の変動と関連させながら，既往の デー夕に基づいて考察した。硫黄酸化細菌を共生させる種 の炭素同位体組成は，溶存重炭酸 $\left(\delta^{13} \mathrm{C}=0 \%\right.$ o $)$ が Rubisco の触媒作用によって還元されるために，おおよそ－35士 5\%。付近に収敛した．メタン酸化細菌を共生させている種 は, メタンの多様な起源を反映して, 著しく軽い軟体部 $\left(\delta^{13} \mathrm{C}=-75 \%\right)$ 加ら, 反対に著しく重いあの $\left(\delta^{13} \mathrm{C}=\right.$ -19\%0) まで観察された。メタン酸化細菌のみを体内共生 させている種では，海水硫酸イオンが主要な硫黄栄羡源で あるために，海水硫酸イオン $\left(\delta^{34} \mathrm{~S}=+21 \%\right.$ 年) の取り込みに 伴う動力学的な, 負の同位体効果を伴っ $\tau$, 軟体部の $\delta^{34} \mathrm{~S}$ 值は, +13 加ら $+16 \%$ の比較的狭い範囲内に収まった。 硫黄酸化細菌が共生する種の $\delta^{34} \mathrm{~S}$ 値は，マグマ性硫化水素

Table 4. Concentration of ammonia in hydrothermal vent and sediment-pore waters relevant to the chemosynthesis-based animal community.

\begin{tabular}{|c|c|c|}
\hline Location of sample water & Concentration of $\mathrm{NH}_{3}$ & Reference \\
\hline & -Hydrothermal vent water- & \\
\hline Okinawa Trough, Iheya CLAM site & $10 \sim 4,450$ & Gamo et al. 1991 \\
\hline Okinawa Trough, Izena JADE site & $240 \sim 4,940$ & Gamo et al. 1991 \\
\hline Okinawa Trough, Minami-Ensei Knoll & $45,600 \sim 4,700$ & Chiba et al. 1993 \\
\hline $47^{\circ} \mathrm{N}$, East Pacific Rise & $640 \sim 950$ & Cowen et al. 1998 \\
\hline \multirow[t]{2}{*}{ Central Indian Ridge, RTJ } & $<10$ & Yamanaka, T. unpublished \\
\hline & -Pore water from sediment- & \\
\hline Sagami Bay, off Hatsushima & to 1,760 & Masuzawa et al. 1992 \\
\hline Aleutian Trench & up to 3,000 & Suess et al. 1998 \\
\hline Oregon Subduction Zone & up to 1,000 & Suess et al. 1989 \\
\hline
\end{tabular}

Concentration: $\mu \mathbf{M}$ 
や硫酸還元菌による海水硫酸イオンの還元に由来する軽い 硫化水素に対応して幅広い変動をした。硫黄酸化細菌㧍よ びメタン酸化細菌を同時に共生させる種の硫黄の安定同位 体組成は, 海水硫酸と局所的な硫化物態硫黄の 2 成分混合 を示唆する中間的な值となった，陸生や浅海の生物群集の 多くが, プラスの $\delta^{15} \mathrm{~N}$ 值を示す一般的な傾向とは異なり, 化学合成生物群集のベントスの中には, 功なり軽い $\delta^{15} \mathrm{~N}$ 值 $(-10 \%$ まで ) を示すあのがしばしば見出された。この 軽い窒素が, 給源堂素の特異性に由来しているのか, ある いは共生細菌一宿主間の代謝過程を通じての窒素同位体分 別の結果に由来するか明らかにするためには，今後は生息 環境中のアンモ二アの窒素同位体組成の測定值が不可欠で ある.

謝 辞：本特集号の企画にあたり，海洋科学技術センターの藤 倉克則博士之編集委員長の大越和加博士は寄稿の機会を与えてい ただいたと同時に，匿名のレフェリーととあに本稿改訂に多くの ご意見・ご討議をいただいた，また，執筆にあたり海洋科学技術 センターの藤原義弘博士には Alvinichoncha 属腹足類関連の資料 をこ教示いただいた，これらの皆样に記して感謝致します。

\section{引用文献}

Barry, J. P., H. G. Greene, D. L. Orange, C. H. Baxter, B. H. Robison, R. E. Kochevar, J. W. Nybakken, D. L. Reed and C. M. McHugh 1996. Biological and geologic characteristics of cold seeps in Monterey Bay, California. Deep-Sea Research I, 43: 1739 1762.

Brooks, J. M., M. C. Kennicutt II, C. R. Fisher, S. A. Macko, K. Cole, J. J. Childress, R. R. Bidigare and R. D. Vetter 1987. Deepsea hydrocarbon seep communities: evidence for energy and nutritional carbon sources. Science, 238: 1138-1142.

Boulègue, J., E. L. Benedetti, D. Dron, A. Mariotti and R. Letolle 1987. Geochemical and biogeochemical observations on the biological communities associated with fluid venting in Nankai Trough and Japan Trench subduction zones. Earth and Planetary Science Letters, 83: 343-355.

Cary, S. C., C. R. Fisher, H. Felbeck and R. D. Vetter 1989. Multiple trophic resources for a chemoautotrophic community at a cold water brine seep at the base of the Florida Escarpment. Marine Biology, 100: 411-418.

下葉 伍・酒井均・蒲生俊敬 - 石橋純一郎 - 中島和夫 - 南 秀 樹・土橋 史 1992 . 南奄西海丘で湧出している気泡の化学・ 同位体組成。第 8 回しんかいシンポジューム報告書, 81-87.

下葉 1 . 中島和夫 - 蒲生俊敬 - 石橋純一郎 - 角皆 潤 - 酒井 均 1993. 沖縄トラフ南奄西海丘の海底熱水活動: 熟水の地球化 学的特徴. 第 9 回しんかいンンポシューム報告㫷, 271-282.

Colaço, A., F. Dehairs and D. Desbruyeres 2002. Nutritional relations of deep-sea hydrothermal fields at the Mid-Atlantic Ridge: a stable isotope approach. Deep-Sea Research I, 49: 395-412.

Corliss, J. B., J. Dymond, L. I. Gordon, J. M. Edmond, R. P. von Herzen, R. D. Ballard, K. Green, D. Williams, A. Bainbridge, K. Crane and T. H. van Andel 1979. Submarine thermal springs on the Galápagos Rift. Science, 203: 1073-1083.

Cowen, J. P., X. Wen, R. D. Jones and R. E. Thomson 1998. Elevated $\mathrm{NH}_{4}{ }^{+}$in a naturally buoyant hydrothermal plume. Deep-Sea Research I, 45: 1891-1902.
Dubilier, N., R. Windoffer and O. Giere 1998. Ultrastructure and stable carbon isotope composition of the hydrothermal vent mussels Bathymodiolus brevior and $B$. sp. affinis brevior from the North Fiji Basin, western Pacific. Marine Ecology Progress Series, 165: 187-193.

Endow, K. and S. Ohta 1989. The symbiotic relationship between bacteria and a mesogastropod snail, Alvinichoncha hessleri, collected from hydrothermal vents of the Mariana Back-Arc Basin. Bulletin of Japanese Society of Microbial Ecology, 3: 73-82.

Exley, R. A., S. R. Boyd, D. P. Mattey and C. T, Pillinger 1987. Nitrogen isotope geochemistry of basaltic glasses: implications for mantle degassing and structure. Earth and Planetary Science Letters, 81: 163-174.

Fiala-Médioni, A., J. Boulègue, S. Ohta, H. Felbeck and A. Mariotti 1993. Source of energy sustaining the Calyptogena populations from deep trenches in subduction zones off Japan. Deep-Sea Research I, 40: 1242-1258.

Fisher, C. R., J. J. Childress and A. J. Arp 1988. Variation in the hydrothermal vent clam Calyptogena magnifica, at Rose Garden vent on the Galapagos spreading center. Deep-Sea Research, 35: 1811-1831.

Fry, B. 1983. Fish and shrimp migrations in the northern Gulf of Mexico analysed using stable $\mathrm{C}, \mathrm{N}$, and $\mathrm{S}$ isotope ratios. Fishery Bulletin, 81: 789-01.

Fry, B., H. Gest and J. M. Hayes 1983. Sulphur isotope composition of deep-sea hydrothermal vent animals. Nature, 306: 51-52.

Fry, B. 1988. Food web structure on Georges Bank from stable C, $\mathrm{N}$, and $\mathrm{S}$ isotopic compositions. Limnology and Oceanography, 33: 1182-1190.

Fujioka, K., T. Yamanaka, T. Gamo, F. Inagaki, T. Miwa and Sato. H. 2001. An introduction to the serpentine biosphere in the Mariana Forearc. 地震研究所拣報, 76: 271-289.

Fujiwara, Y., K. Takai, K. Uematsu, S. Tsuchida, J. C. Hunt and J. Hashimoto 2000. Phylogenetic characterization of endosymbionts in three hydrothermal vent mussels: influence on host distributions. Marine Ecology Progress Series, 208: 147-155.

Fujiwara, Y., S. Kojima, C. Mizota, Y. Maki and K, Fujikura 2000. Phylogenetic characterization of the endosymbionts of the deepestliving vesicomyid clam, Calyptogena fossajaponica, from the Japan Trench. Venus, 59: 307-316.

Gamo, T., H. Sakai, E.-S. Kim, K. Shitashima and J. Ishibashi 1991. High alkalinity due to sulfate reduction in the Clam hydrothermal field, Okinawa Trough. Earth and Planetary Science Letters, 107: 328-338.

Gamo, T., H. Chiba, T. Yamanaka, T. Okudaira, J. Hashimoto, S. Tsuchida, J. Ishibashi, S. Kataoka, U. Tsunogai, F. Kouzuma, K. Okamura, Y. Sano and R. Shinjo 2001. Chemical characteristics of newly discovered black-smoker fluids and associated hydrothermal plumes at the Rodriguez Triple Junction, Central Indian Ridge. Earth and Planetary Science Letters, 193: 371-379.

服部睦男 - 蟹江康光 - 大場忠道 - 秋元和賽 1996. 相模湾の沈み 込子帯の冷湧水域に伴う炭酸塩類と化学合成独立栄養動物群集 の環境. 化石, 60: 13-22.

Jannasch, H. W, and C. O. Wirsen 1979. Chemosynthetic primary production at East Pacific sea floor spreading centers. Bioscience, 29: 592-598.

Kenk, V. C. and B. R. Wilson 1985. A new mussel (Bivalvia, Mytilidae) from hydrothermal vents in the Galapagos Rift zone. Malacologia, 26: 253-271.

Kennicutt II, M. C., J. M. Brooks, R. R. Bidigare, R. R. Fay, T. L. Wade and T. McDonald 1985. Vent-type taxa in a hydrocarbon 
seep region on the Lousiana slope. Nature, 317: 351-353.

Kennicutt II, M. C., J. M. Brooks, R. R. Bidigare, S. J. McDonald, D. L. Adkinson and S. A. Macko 1989. An upper slope "cold" seep community: Northern California. Limnology and Oceanography, 34: 635-640.

Kennicutt II, M. C., R. A. Burke, I. R. MacDonald, J. M. Brooks, G. J. Denoux and S. A. Macko 1992. Stable isotope partitioning in seep and vent organisms-chemical and ecological significance. Chemical Geology, 101: 293-310.

Kim, E. S., H. Sakai, J. Hashimoto, F. Yanagisawa and S. Ohta 1989. Sulfur isotopic ratios of hydrothermal vent-animals at Ogasawara Arc and Mid-Okinawa Trough-evidence for microbial origin of hydrogen sulfide at low-temperature submarine hydrothermal areas. Geochemical Journal, 23: 195-208.

金 銀洙・酒井 均・蒲生俊敬・橋本 惊 -太田 秀 - 柳澤文孝 1990. 沖縄トラフ熱水生物の炭素, 窒菜および硫黄同位体比. 第 6 回「しんかい2000」研究シンボジゥム報告書, 129-137.

Kulm, L. D., E. Suess, J. C. Moore, B. Carson, B. T. Lewis, S. D. Ritger, D. C. Kadko, T. M. Thornburg, R. W. Embley, W. D. Rugh, G. J. Massoth, M. G. Langseth, G. R. Cochrane and R. L. Scamman 1986. Oregon subduction venting, fauna and carbonates. Science, 231: 561-566.

Lonsdale, P. 1977. Clustering of suspension feeding macrobenthos near abyssal hydrothermal vents at oceanic spreading centers. Deep-Sea Research, 24: 857-863.

牧 晹之助・溝田智俊 1997. マリアナ背弧海盆のアルヴィンガ 1 (Alvinichoncha hessleri) 及びシュリンプ (Chorocaris vandoverae) の硫黄同位体組成. JAMSTEC 深海研究, 13: 63-67.

Masuzawa, T., N. Handa, H. Kitagawa and M. Kusakabe 1992. Sulfate reduction using methane in sediments beneath a bathyal "cold seep" giant clam community off Hatsushima Island, Sagami Bay, Japan. Earth and Planetary Science Letters, 119: 39-50.

Minagawa, M. and E. Wada 1984 . Stepwise enrichment of ${ }^{15} \mathrm{~N}$ along food chains: Further evidence and the relation between $\delta^{15} \mathrm{~N}$ and animal age. Geochimica et Cosmochimica Acta, 48: 1135-1140.

Miura, T., M. Nedachi and J. Hashimoto 2002. Sulphur sources for chemoautotrophic nutrition of shallow water vestimentiferan tubeworm in Kagoshima Bay. Journal of the Marine Biological Association of the United Kingdom, 82: 537-540.

Mizota, C. and Y. Maki 1998. Sulfur isotopic variations in soft tissues of Calyptogena soyoae from Sagami Bay, central Japan. Geochemical Journal, 32: 421-425.

Mizota, C. and Y. Maki 1999. Use of hydrogen sulfide dissolved in thermal waters by sulfur-oxidizing bacteria: a sulfur isotopic approach. Geochemical Journal, 33: 67-71.

Mottl, M. J. 1992. Pore waters from serpentine seamounts in the Mariana and Izu-Bonin Forearcs, Leg 125. Evidence for volatiles from the subducting slab. In, Proceedings of the Ocean Drilling Program. Scientific Results, 125: 373-385.

Nelson, D. C. and C. R. Fisher 1995. Chemoautotrophic and methanotrophic endosymbiotic bacteria at deep-sea vents and seeps. In, The Microbiology of Deep-Sea Hydrothermal Vents, D. M. Karl (ed.), CRC Press, Boca Raton and New York, pp. 125-167.

Peterson, B. J. and R. W. Howarth 1987. Sulfur, carbon, and nitrogen isotopes used to trace organic matter flow in the salt-marsh estuaries of Sapelo Island, Georgia. Limnology and Oceanography, 32: 1195-12134.

Paull, C. K., J. T. Jull, L. J. Toolin and T. S. Linick 1985. Stable isotope evidence for chemosynthesis in an abyssal seep community. Nature, 317: 709-711.

Paull, C. K., C. S. Martens, J. P. Chanton, A. C. Neumann, J. Cos- ton, A. J. T. Jull and L. J. Toolin 1989. Old carbon in living organisms and young $\mathrm{CaCO}_{3}$ cements from abyssal brine seeps. Nature, 342: 166-168.

Pond, D. W., M. V. Bell, D. R. Dixon, A. E. Fallick, M. Segonzac and J.R. Sargent 1998. Stable-carbon-isotope composition of fatty acids in hydrothermal vent mussels containing methanotrophic and thiotrophic bacterial endosymbionts. Applied and Environmental Microbiology, 64: 370-375.)

Rau, G. H. 1981. Hydrothermal vent clam and tube worm ${ }^{13} \mathrm{C} /{ }^{12} \mathrm{C}$ : further evidence of nonphotosynthetic food sources. Science, 213: 338-340.

Rau, G. H., C. M. McHugh, C. Harrold, C. Baxter, B. Hecker and R. W. Embley $1990 .{ }^{13} \mathrm{C},{ }^{15} \mathrm{~N}$ and ${ }^{18} \mathrm{O}$ of Calyptogena phaseoliformis (bivalve mollusk) from the Ascension Fan-Valley near Monterey, California. Deep-Sea Research, 37: 1669-1990.

Rees, C. E., W. J. Jenkins and J. Monster 1978. The sulphur isotopic composition of ocean water sulphate. Geochimica et Cosmochimica Acta, 42: 377-381.

Robinson, J. J., M. F. Polz, A. Fiala-Médioni and C. M. Cavanaugh 1998. Physiological and immunological evidence for two distinct $\mathrm{C}_{1}$-utilizing pathways in Bathymodiolus puteoserpentis (Bivalvia: Mytilidae), a dual endosymbiotic mussel from the Mid-Atlantic Ridge. Marine Biolology, 132: 625-633.

Ruby, E. G., H. W. Jannasch and W. G. Deuser 1987. Fractionation of stable isotopes during chemoautotrophic growth of sulfuroxidizing bacteria. Applied and Environmental Microbiology, 53: 1940-1943.

Sackett, W. M. and R. R. Thompson 1963. Isotopic organic carbon composition of recent continental derived clastic sediments of eastern gulf coast, Gulf of Mexico. Bulletin of the American Association of Petroleum Geologists, 47: 525-528.

Sakai, H., T. Gamo, K. Endow, J. Ishibashi, T. Ishizuka, F. Yanagisawa, M. Kusakabe, T. Akagi, G. Igarashi and S. Ohta 1987. Geochemical study of the bathyal seep communities at the Hatsushima site, Sagami Bay, central Japan. Geochemical Journal, 21: 227-236.

Sakai, H., T. Gamo, E.-S. Kim, K. Shitashima, F. Yanagisawa, M. Tsutsumi, J. Ishibashi, Y. Sano and H. Wakita 1990. Unique chemistry of the hydrothermaql solution in the mid-Okinawa Trough backarc basin. Geophysical Research Letters, 17: 21332136.

酒井 均 - 松久幸敬 1996. 安定同位体地球化学, 東京大学出版 会, 東京, 403 pp.

Saino, T. and S. Ohta $1989 .{ }^{13} \mathrm{C} /{ }^{12} \mathrm{C}$ and ${ }^{15} \mathrm{~N} /{ }^{14} \mathrm{~N}$ ratios of vesicomyid clams and a vestimentiferan tube worm in the subduction zone east of Japan. Palaeogeography, Palaeoclimatology and Palaeoecology, 71: 169-178.

Schoell, M. 1988. Multiple origins of methane in the earth. Chemical Geology, 71: 1-10.

Stein, J. L., S. C. Cary, R. R. Hessler, S. Ohta, R. D. Vetter, J. J. Childress and H. Felbeck 1988. Chemoautotrophic symbiosis in a hydrothermal vent gastropod. Biological Bulletin, 174: 373-378.

Suess, E. and M. J. Whiticar 1989. Methane-derived $\mathrm{CO}_{2}$ in pore water fluids expelled from the Oregon subduction zone. Palaeogeography, Palaeoclimatology and Palaeoecolology, 71: 119-136.

Suess, E., G. Bohrmann, R. von Huene, P. Linke, G. Winckler, R. A. Lutz and D. Orange 1998. Fluid venting in the eastern Aleutian subduction zone. Journal of Geophysical Research-Solid Earth, 103: 2597-2614.

Trask, J. L. and C. L. Van Dover 1999. Site-specific and ontogenetic variations in nutrition of mussels (Bathymodiolus sp.) from the 
Lucky Strike hydrothermal vent field, Mid-Atlantic Ridge. Limnology and Oceanography, 44: 334-343.

Tsunogai, U., J. Ishibashi, H. Wakita, T. Gamo, K. Watanabe, S. Kanayama, H. Sakai and T. Kajimura 1994. Peculiar features of Suiyo Seamount hydrothermal fluids, Izu-Bonin arc: Differences from subaerial volcanism. Earth and Planetary Science Letters, 126: 289-301.

Tsunogai, U., N. Yoshida, J. Ishibashi and T. Gamo 2000. Carbon isotopic distribution of methane in deep-sea hydrothermal plume, Myojin Knoll Caldera, Izu-Bonin are: Implications for microbial methane oxidation in the oceans and applications to heat flux estimation. Geochimica et Cosmochimica Acta, 64: 2439-2452.

Van Dover, C. L. and B. Fry 1989. Stable isotopic compositions of hydrothermal vent organisms. Marine Biology, 102; 257-263.

Van Dover, C. L. 2000. The Ecology of Deep-Sea Hydrothermal Vents. Princeton University Press, Princeton, New Jersey, 424 pp.

Van Dover, C. L., S. E. Humphris, D. Fornari, C. M. Cavanaugh, R. Collier, S. K. Goffredi, J. Hashimoto, M. D. Lilley, A. L. Reysenbach, T. M. Shank, K. L. Von Damm, A. Banta., R. M. Gallant, D. Götz, D. Green, J. Hall, T. L. Harmer, L. A. Hurtado, P. Johnson, Z. P. McKiness, C. Meredith, E. Olson, I. L. Pan, M. Turnipseed, Y. Won, C. R. Young III and R. C. Vrijenhoek 2001. Biogeography and ecological setting of Indian Ocean hydrothermal vents. Science, 294: 818-823.

Van Dover, C. L. 2002. Trophic relationships among invertebrates at the Kairei hydrothermal vent field (Central Indian Ocean Ridge). Marine Biology, 141: 761-772.
Welhan, J. A. and H. Craig 1983. Methane, hydrogen and helium in hydrothermal fluids at $21^{\circ} \mathrm{N}$ on the East Pacific Rise. In, Hydrothermal Process at Seafloor Spreading Centers, Rona, P. A. et al. (eds.), Plenum Press, New York, pp. 391-409.

Yamanaka, T., C. Mizota, Y. Fujiwara, H. Chiba, J. Hashimoto, T. Gamo and T. Okudaira 2003a. Sulfur-isotopic composition of the deep-sea mussel Bathymodiolus marisindicus from currently active hydrothermal vents in the Indian Ocean. Journal of the Marine Biological Association of the United Kingdom. (in press)

Yamanaka, T., C. Mizota, Y. Maki, K. Fujikura and H. Chiba 2000. Sulfur isotope composition of soft tissues of deep-sea mussels. Bathymodiolus spp., in Japanese waters. Benthos Research, 55: $63-$ 68.

Yamanaka., T., C. Mizota, H. Satake, F. Kouzuma, T. Gamo, U. Tsunogai, T. Miwa and K. Fujioka 2003b. Stable isotope evidence for a putative endosymbiont-based lithotrophic Bathymodiolus sp. mussel community atop a serpentine seamount. Geomicrobiology Journal. (in press)

Yamanaka, T., C. Mizota and S. Shimoyama 2003c. Sulfur isotopic variations in soft tissues of five benthic animals from the reductive tidal flat sediments in northern Kyushu, Japan. Marine Biology, 142: 327-331.

Yamanaka, T., S. Shimoyama and C. Mizota 2000. An evaluation of source sulfur in soft tissues of marine and freshwater benthic animals from Japan using stable isotope analysis. Benthos Research, 55: 17-22. 